\title{
Analisis Kontribusi Pendapatan Sektor Pariwisata terhadap Pendapatan Asli Daerah Kabupaten Gianyar
}

\section{Gusti Ayu Herlin Mardiana ${ }^{1}$ \\ Fakultas Ekonomi dan Bisnis \\ Universitas Udayana, Indonesia}

\begin{abstract}
Surel : gekliendiana@gmail.com
ABSTRAK

Penelitian ini menganalisis tiga variabel yaitu PAD Kabupaten Gianyar, PHR dan retribusi tempat rekreasi dan olah raga. Alat analisis yang digunakan dalam penelitian ini adalah analisis kontribusi, regresi linear. Penelitian ini menggunakan data sekunder, sehingga metode pengumpulan data yang digunakan adalah metode observasi non-partisipan. Berdasarkan hasil analisis, diketahui bahwa kontribusi pendapatan sektor pariwisata dari PHR dan retribusi tempat rekreasi dan olah raga mencapai rata-rata 44,71 persen selama tahun 2002-2017. Hasil penelitian ini dapat menjadi rujukan bagi Pemerinah Kabupaten Gianyar bahwa Pendapatan dari sektor pariwisata memiliki kontribusi yang besar terhadap PAD Kabupaten Gianyar, sehingga Pemerintah Kabupaten Gianyar semakin termotivasi untuk terus meningkatkan sarana dan prasarana di bidang pariwisata yang dapat menunjang peningkatan pendapatan dari sector pariwisata dimaksud.
\end{abstract}

Kata Kunci: Pajak Hotel dan Restoran; Retribusi Tempat Rekreasi dan Olah Raga; Pendapatan Asli Daerah.

\section{Analysis of the Contribution of Tourism Sector Revenue to Local Revenue in Gianyar Regency}

\begin{abstract}
This study analyzes three variables, namely Gianyar Regency PAD, $P H R$ and retribution for recreation and sports. The analytical tool used in this study is contribution analysis, linear regression. This study uses secondary data, so that the data collection method used is the method of non-participant observation. Based on the results of the analysis, it is known that the contribution of tourism sector revenues from PHR and retribution for recreation and sports reached an average of 44.71 percent during 2002-2017. The results of this study can be a reference for the Gianyar Regency Government that revenue from the tourism sector has a large contribution to the Gianyar Regency PAD, so the Gianyar Regency Government is increasingly motivated to continue to improve facilities and infrastructure in the tourism sector that can support increased income from the tourism sector.
\end{abstract}

Keywords: $\quad$ Hotel And Restaurant Tax; Retribution For Recreation And Sports; Local Revenue.

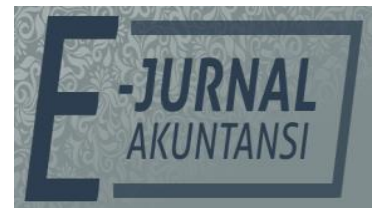

e-ISSN 2302-8556

Vol. 31 No. 1

Denpasar, Januari 2021 Hal. 259-274

DOI:

10.24843/EJA.2021.v31.i01.p20

PENGUTIPAN

Mardiana, G.A.H. (2021).

Analisis Kontribusi

Pendapatan Sektor

Pariwisata terhadap

Pendapatan Asli Daerah

Kabupaten Gianyar. E-Jurnal Akuntansi, 31(1), 259-274

RIWAYAT ARTIKEL:

Artikel Masuk:

4 Juli 2019

Artikel Diterima: 17 Januari 2021

Artikel dapat diakses : https://ojs.unud.ac.id/index.php/Akuntansi/index 


\section{PENDAHULUAN}

Pembangunan pada dasarnya merupakan upaya suatu negara untuk meningkatkan kesejahteraan masyarakatnya dengan menghasilkan produk dan jasa yang baik, disertai berbagai kegiatan usaha yang dapat meratakan distribusi pendapatan nasional (Ratnawati, 2016). Peningkatan pertumbuhan ekonomi serta usaha lainnya secara berkesinambungan tidak terlepas dari tersedianya sumber daya baik secara kualitas maupun kuantitas untuk dapat dimanfaatkan secara optimal (Rahmawati, 2018).

Untuk mewujudkan pembangunan yang dapat meningkatkan kualitas kehidupan masyarakat bukanlah hal yang mudah, karena hampir setiap daerah dihadapkan dengan masalah keuangan (Mayasari \& Rahardjo, 2018). Suahasil, (1997) mengatakan bahwa pembangunan yang menjadi kewajiban Pemerintah Daerah dibiayai dari sumber Anggaran Pendapatan dan Belanja Daerah (APBD) yang menggambarkan kemampuan daerah dalam memobilisasi potensi keuangannya. Dengan demikian pemerintah daerah berkewajiban meningkatkan secara terus menerus penerimaan daerahnya sehingga ketergantungan terhadap pemerintah pusat dapat dikurangi (Purwanti \& Dewi, 2014). Penyelenggaraan kepariwisataan diarahkan untuk peningkatan kesejahteraan dan kemakmuran rakyat dalam rangka mewujudkan masyarakat adil dan makmur melalui peningkatan devisa, perluasan dan pemerataan kesempatan usaha dan lapangan kerja, mendorong pembangunan daerah, memperkaya kebudayaan nasional dengan tetap melestarikan kepribadian bangsa dan terpeliharanya nilai-nilai agama (Rosa, et al., 2016).

Dengan disahkannya Undang-undang Nomor 22 Tahun 1999 Jo UU No. 32 Tahun 2004 tentang Pemerintah Daerah dan Undang-undang Nomor 25 Tahun 1999 JO UU Nomor 33 Tahun 2004 tentang Perimbangan Keuangan antara Pemerintah Pusat dan Daerah, maka daerah memiliki kewenangan yang semakin luas untuk memberdayakan diri terutama berkaitan dengan sumber daya yang dimiliki (Suarjana, et al., 2019). Ciri utama yang mewujudkan suatu daerah otonom mampu berotonomi, terletak pada kemampuan keuangan daerah, artinya daerah otonom harus mampu memiliki kewenangan dan kemampuan untuk menggali sumber-sumber keuangannya sendiri, mengelola dan menggunakan keuangannya sendiri yang cukup memadai untuk membiayai penyelenggaraan pemerintah daerahnya (Oomariyah, 2017). Pemerintah daerah dituntut untuk menciptakan kemandirian daerah yang dapat memacu pertumbuhan daerah, oleh karena itu kemandirian harus diikuti oleh kemampuan keuangan daerah yang meyakinkan, yaitu Pendapatan Asli Daerah (PAD) harus menjadi bagian sumber keuangan terbesar untuk menutupi baik pengeluaran rutin maupun pengeluaran pembangunan, dan ketergantungan kepada bantuan pusat harus seminimal mungkin (Oomariyah, 2017).

Pariwisata merupakan salah satu sektor utama dalam pembangunan ekonomi (Nugraha, 2014). Sektor pariwisata merupakan sektor yang potensial untuk dikembangkan sebagai salah satu sumber pendapatan daerah (Purwanti \& Dewi, 2014). Untuk memperbesar pendapatan asli daerah, maka program pengembangan dan pendayagunaan sumber daya dan potensi pariwisata daerah diharapkan dapat memberikan sumbangan dalam kegiatan ekonomi (Sijtsma, et al., 2015). Upaya menciptakan kemandirian daerah, pendapatan asli daerah 
menjadi faktor yang sangat penting, dimana PAD akan menjadi sumber dana dari daerah sendiri. Salah satu sektor yang sangat potensial untuk dikembangkan atau dapat dijadikan andalan bagi pemasukan pendapatan asli daerah (PAD) yaitu dari sektor pariwisata, karena sektor pariwisata memiliki kontribusi dalam penerimaan pendapatan dan penyerapan tenaga kerja. Penerimaan sektor pariwisata bersumber dari pajak hotel dan restoran, pajak hiburan dan retribusi objek wisata berupa karcis masuk ke obyek wisata. Penerimaan sektor pariwisata inilah yang nantinya menjadi salah satu penambah pendapatan asli daerah (Rasdiana, 2017).

Secara luas pariwisata dipandang sebagai kegiatan yang mempunyai multidimensi dari rangkaian suatu proses pembangunan (Wulandari \& Triandaru, 2016). Pembangunan sektor pariwisata menyangkut aspek sosial budaya, ekonomi dan politik (Spillane, 1994). Hal tersebut sejalan dengan yang tercantum dalam Undang-Undang Nomor 10 Tahun 2009 tentang Kepariwisataan yang menyatakan bahwa kepariwisataan merupakan bagian integral dari pembangunan nasional yang dilakukan secara sistematis, terencana, terpadu, berkelanjutan, dan bertanggung jawab dengan tetap memberikan perlindungan terhadap nilai-nilai agama, budaya yang hidup dalam masyarakat, kelestarian dan mutu lingkungan hidup, serta kepentingan nasional (Swantara \& Darsana, 2017).

Kabupaten Gianyar merupakan salah satu kabupaten di Bali yang terkenal sebagai daerah tujuan utama wisatawan yang datang ke Bali. Kabupaten Gianyar merupakan daerah yang giat mengembangkan potensi wilayahnya untuk tujuan wisata. Obyek dan Daya Tarik Wisata (ODTW) yang dimiliki Kabupaten Gianyar cukup banyak dan bervariasi, mulai dari budaya daerah, kebun binatang, gua, agrowisata, situs purbakala, arung jeram, hingga museum. Arus wisatawan baik dari manca negara maupun dalam negeri yang mengunjungi Kabupaten Gianyar semakin meningkat dari tahun ke tahun (Pleanggra, 2012).

Tabel 1. Target dan Realisasi PAD Kabupaten Gianyar Tahun Anggaran 20072017

\begin{tabular}{cccc}
\hline No. & Tahun Anggaran & $\begin{array}{c}\text { Pendapatan Asli Daerah } \\
\text { (dalam Rp. Juta) } \\
\text { Realisasi (Rp) }\end{array}$ & $\begin{array}{c}\text { Prosentase (\%) } \\
\text { Peningkatan }\end{array}$ \\
\hline 1 & 2007 & $75.129,63$ & - \\
2 & 2008 & $96.922,24$ & 29,01 \\
3 & 2009 & $112.724,49$ & 14,02 \\
4 & 2010 & $153.617,90$ & 36,96 \\
5 & 2011 & $209.598,19$ & 36,29 \\
6 & 2012 & $261.222,18$ & 24,88 \\
7 & 2013 & $319.612,00$ & 22,25 \\
8 & 2014 & $424.782,24$ & 30,30 \\
9 & 2015 & $457.321,02$ & 7,74 \\
10 & 2016 & $529.864,62$ & 15,86 \\
11 & 2017 & $697.996,68$ & 24,09 \\
\hline
\end{tabular}

Sumber: Data Penelitian, 2019

Berdasarkan Tabel 1, dapat dilihat bahwa PAD Kabupaten Gianyar mulai tahun 2010 mengalami kenaikan yang cukup signifikan, hal ini disebabkan karena sektor pariwisata di Pulau Bali khusunya Kabupaten Gianyar mulai 
mengalami kemajuan sehingga berpengaruh pada pendapatan asli daerah kabupaten Gianyar mengingat PAD Kabupaten Gianyar sebagian besar bersumber dari sektor pariwisata (BPS, 2018).

Tabel 2. Perkembangan Jumlah Wisatawan Di Kabupaten Gianyar Tahun 2013-2017

\begin{tabular}{rrrrrr}
\hline \multirow{2}{*}{ No. } & \multirow{2}{*}{ Tahun } & \multicolumn{2}{c}{ Jenis Tamu } & Jumlah (org) & $\begin{array}{r}\text { Pertumbuhan } \\
(\%)\end{array}$ \\
\hline 1 & 2013 & 1.073 .113 & 585.682 & 1.658 .795 & - \\
2 & 2014 & 1.254 .243 & 667.576 & 1.921 .819 & 13,69 \\
3 & 2015 & 1.278 .628 & 639.063 & 1.917 .691 & 0,22 \\
4 & 2016 & 2.339 .789 & 613.842 & 2.953 .631 & 35,07 \\
5 & 2017 & 3.180 .778 & 661.885 & 3.842 .663 & 23,14 \\
\hline
\end{tabular}

Sumber: Data Penelitian, 2019

Perkembangan Jumlah Wisatawan mancanegara dan domestik di Kabupaten Gianyar selama periode tahun 2013 sampai dengan 2015 mengalami kenaikan yang cukup tinggi, terutama pada tahun 2016 pertumbuhan wisatawan mancanegara dan domestik mencapai 35,07 persen. Dengan tingginya jumlah wisatawan di Kabupaten Gianyar akan meningkatkan pendapatan sektor pariwisata seperti PHR Kabupaten Gianyar (BPS, 2018).

Tabel 3. Target dan Realisasi Pajak Hotel dan Restoran (PHR) Kabupaten Gianyar Tahun Anggaran 2007-2017

\begin{tabular}{ccccc}
\hline \multirow{2}{*}{ No. } & \multirow{2}{*}{ Tahun Anggaran } & \multicolumn{2}{c}{$\begin{array}{c}\text { Pajak Hotel dan Restoran } \\
\text { (dalam Rp. Juta) }\end{array}$} & \multirow{2}{*}{ Prosentase (\%) } \\
\cline { 3 - 4 } & & Target & Realisasi & \\
\hline 1 & 2007 & $26.000,0$ & $28.555,6$ & 109,83 \\
2 & 2008 & $28.463,4$ & $43.586,2$ & 153,13 \\
3 & 2009 & $43.600,1$ & $47.916,1$ & 109,90 \\
4 & 2010 & $51.020,2$ & $62.918,1$ & 123,32 \\
5 & 2011 & $62.016,0$ & $79.110,6$ & 127,56 \\
6 & 2012 & $75.500,0$ & $86.104,7$ & 114,05 \\
7 & 2013 & $86.104,7$ & $106.866,2$ & 124.11 \\
8 & 2014 & $98.035,8$ & $145.070,5$ & 147,98 \\
9 & 2015 & $124.000,0$ & $161.376,3$ & 130,14 \\
10 & 2016 & $175.000,0$ & 206849,4 & 118,20 \\
11 & 2017 & $235.824,6$ & $260.830,8$ & 110,60 \\
\hline
\end{tabular}

Sumber: Data Penelitian, 2019

Melihat Tabel 3, nampaknya pada tahun 2014 terjadi kenaikan signifikan terhadap target dan realisasi PHR di Kabupaten Gianyar. Hal ini disebabkan karena banyaknya event berskala international yang diadakan di Pulau Bali. Sedangkan untuk pendapatan sektor pariwisata dari penerimaan Retribusi Tempat Rekreasi dan Olahraga yang dikelola Pemerintah Kabupaten Gianyar disajikan dalam Tabel 4.

Pendapatan sektor pariwisata dari penerimaan Retribusi Tempat Rekreasi dan Olahraga yang dikelola Pemerintah Kabupaten Gianyar dari periode 2007 sampai dengan 2017 cenderung stabil. Peningkatan yang cukup signifikan terjadi pada tahun 2017 yaitu realisasi melampaui target hingga 29,63 persen sehingga mencapai Rp. 18.782.660.000,00 (BPS, 2018). 
Tabel 4. Target dan Realisasi Penerimaan Retribusi Tempat Rekreasi dan Olah Raga yang Dikelola Oleh Pemerintah Kabupaten Gianyar Tahun 2007-2017

\begin{tabular}{rcccc}
\hline \multirow{2}{*}{ No. } & Tahun & \multicolumn{2}{c}{$\begin{array}{c}\text { Retribusi Tempat Rekreasi } \\
\text { (dalam Rp. Juta) }\end{array}$} \\
\cline { 3 - 4 } & & Target & Realisasi & Prosentase (\%) \\
\hline 1 & 2007 & $2.900,00$ & $2.900,19$ & 100,01 \\
2 & 2008 & $3.126,93$ & $3.411,61$ & 109,10 \\
3 & 2009 & $3.517,76$ & $4.176,37$ & 118,72 \\
4 & 2010 & $9.000,00$ & $8.493,88$ & 94,38 \\
5 & 2011 & $12.000,00$ & $11.121,42$ & 92,68 \\
6 & 2012 & $12.000,00$ & 13.563 .70 & 113,03 \\
7 & 2013 & $12.486,99$ & $12.518,30$ & 100,25 \\
8 & 2014 & $12.464,14$ & $13.228,08$ & 106,13 \\
9 & 2015 & $12.464,14$ & $13.619,90$ & 109,27 \\
10 & 2016 & $13.000,00$ & $15.493,35$ & 119,18 \\
11 & 2017 & $14.490,00$ & $18.782,66$ & 129,63 \\
\hline
\end{tabular}

Sumber: Badan Pengelolaan Keuangan dan Aset Daerah Kabupaten Gianyar, 2019

Sektor pariwisata merupakan salah satu sektor yang mendapat prioritas utama dalam rangka memperbaiki struktur ekonomi daerah serta dapat meningkatkan kemandirian dan daya saing, dengan demikian diharapkan mampu memberikan kontribusi yang cukup besar terhadap PAD (Thesaurianto, 2007). Dalam kaitannya sektor pariwisata sebagai sektor andalan di Kabupaten Gianyar sebagai penerimaan daerah, diperlukan peningkatan kualitas kepariwisataan di Kabupaten Gianyar yang akan meningkatkan jumlah kunjungan wisatawan mancanegara maupun domestik yang akan meningkatkan PAD baik berasal dari pajak hotel dan restoran, restribusi sektor pariwisata maupun kegiatan perekonomian lainnya. Berkembangnya industri pariwisata di Kabupaten Gianyar telah mampu menggerakkan sektor-sektor yang mempunyai keterkaitan langsung dengan industri pariwisata, seperti sektor industri pengolahan, hiburan, perdagangan dan juga sektor hotel dan restoran. Adanya perkembangan pada sektor pariwisata membuat terciptanya persaingan antara pelaku usaha tersebut maka wadah untuk pemasaran produk pun semakin banyak dibutuhkan, tidak hanya lewat media cetak, media elektronik juga semakin marak dibutuhkan (Putra, et al., 2017).

$\mathrm{H}_{1}$ : Pajak Hotel dan Restoran dan retribusi tempat rekreasi dan olah raga secara simultan mempunyai pengaruh positif terhadap Pendapatan Asli Daerah.

Lahirnya Pajak Hotel dan Restoran dan retribusi tempat rekreasi dan olah raga merupakan sumber penting dari Pendapatan Asli Daerah (Warda, 2016). Sehingga Pajak Hotel dan Restoran serta retribusi tempat rekreasi dan olah raga tentunya akan cenderung mempengaruhi tingkat Pendapatan Asli Daerah khususnya bagi daerah atau kabupaten yang mengandalkan dari sektor pariwisata (Zulmi, 2018). Penelitian yang dilakukan oleh Suarjana et al., (2019) menyatakan bahwa Retribusi Obyek Wisata berpengaruh signifikan terhadap Daerah (PAD). Berdasarkan uraian dan hasil-hasil penelitian tersebut, maka rumusan hipotesis dalam penelitian ini adalah.

$\mathrm{H}_{2}$ : Pajak Hotel dan Restoran dan retribusi tempat rekreasi dan olah raga secara parsial mempunyai pengaruh positif terhadap Pendapatan Asli Daerah. 


\section{METODE PENELITIAN}

Untuk memberikan gambaran yang jelas mengenai kondisi dan karakteristik obyek penelitian, maka penjelasan terhadap lokasi dan waktu penelitian penting untuk dilakukan. Tempat atau lokasi penelitian ini dilaksanakan di Kabupaten Gianyar. Alasan dipilihnya Kabupaten Gianyar sebagai lokasi penelitian adalah: 1) Peranan pariwisata di Kabupaten Gianyar merupakan komponen utama perekonomian masyarakat, sektor pariwisata merupakan penyumbang terbesar PAD. 2) Pemerintah Kabupaten Gianyar dalam melaksanakan pembangunan, pemerintahan dan pelayanan pada masyarakat memerlukan sejumlah dana untuk membiayai program dan kegiatan daerah. Akan tetapi sumber penerimaan daerah yang berasal dari PAD besarnya belum optimal, oleh karena itu pendapatn dari sektor pariwisata perlu lebih ditingkatkan lagi.

Penelitian dilaksanakan pada tahun 2011 dan data yang dikelola dalam pemelitian ini adalah kondisi tahun 2000-2010. Variabel-variabel yang dibutuhkan dan akan dianalisis dalam penelitian ini meliputi Pendapatan Asli Daerah (PAD) Kabupaten Gianyar, Retribusi tempat rekreasi dan olah raga, Pajak Hotel dan Restoran Kabupaten Gianyar Tahun 2002-2017.

Teknik analisis yang digunakan dalam penelitian ini adalah regresi linier berganda dengan data panel yang diolah menggunakan software komputer SPSS 15.0. Spesifikasi model empiris analisis regresinya dengan model sebagai berikut. $Y_{t}=\beta_{0}+\beta_{1} X_{1 t}+\beta_{2} X_{2 t}+\mu_{t}$

Keterangan:

$Y_{t} \quad:$ variabel dependent (PAD)

$\beta_{0} \quad$ : konstanta

$\beta_{1}, \beta_{2}$ : koefisien regresi

$\mathrm{X}_{1} \quad$ : PHR

$\mathrm{X}_{2} \quad$ : Retribusi tempat rekreasi dan olahraga

$\mu_{\mathrm{t}} \quad$ : tingkat gangguan (disturbance).

\section{HASIL DAN PEMBAHASAN}

Salah satu cara yang dapat digunakan dalam rangka mengoptimalkan penerimaan Pendapatan Asli Daerah dari sektor pariwisata diperlukan suatu kajian dan perhitungan - perhitungan seberapa besar kontribusi pendapatan dari sektor pariwisata yang terdiri dari Pajak Hotel dan Restoran (PHR) dan retribusi tempat rekreasi dan olah raga terhadap Pendapatan Asli Daerah yang dihasilkan dari tahun ketahun. Besaran ini digunakan untuk mengukur seberapa besar sumbangan pendapatan dari sektor pariwisata terhadap penerimaan daerah dalam hal ini Pendapatan Asli Daerah (PAD). Untuk mengetahui seberapa besar peranan atau kontribusi/share dengan cara membandingkan antara realisasi penerimaan PHR dan retribusi tempat rekreasi dan olah raga dengan realisasi Pendapatan Asli Daerah selanjutnya dikalikan 100 persen. Berdasarkan hasil penelitian yang telah dilakukan diperoleh hasil seperti yang terlihat pada Tabel 4.

Berdasarkan Tabel 4, terlihat bahwa peranan PHR dan retribusi obyek wisata terhadap Pendapatan Asli Daerah (PAD) selama kurun waktu 2002 sampai dengan 2017. Kontribusi pendapatan sektor pariwisata selama delapan 
belas tahun otonomi daerah berlangsung menunjukkan kontribusi yang dominan dengan rata-rata 44,71 persen, dimana PHR menunjukkan kontribusi yang besar dengan rata-rata 40,63 persen dan retribusi tempat rekreasi dan olah raga menunjukkan peran yang masih kecil dengan rata-rata 4,08 persen. Rendahnya kontribusi retribusi tempat rekreasi dan olah raga terhadap Pendapatan Asli Daerah (PAD) adalah tidak sesuai dengan kondisi daerah Kabupaten Gianyar yang apabila dilihat sektor pariwisata memiliki potensi yang dapat memberikan sumbangan yang cukup berarti bagi penerimaan daerah namun kenyataannya kontribusinya masih rendah.

Tabel 4. Kontribusi PHR dan Retribusi Tempat Rekreasi dan Olah Raga Terhadap PAD di Kabupaten Gianyar Tahun Anggaran 2002-2017

\begin{tabular}{|c|c|c|c|c|c|c|}
\hline \multirow[b]{2}{*}{ Tahun } & \multicolumn{2}{|c|}{$\begin{array}{l}\text { Pendapatan Sektor Pariwisata } \\
\text { (dalam Rp. Juta) }\end{array}$} & \multirow[b]{2}{*}{$\begin{array}{c}\text { PAD } \\
\text { (dalam Rp. } \\
\text { Juta) }\end{array}$} & \multicolumn{3}{|c|}{ Kontribusi } \\
\hline & PHR & $\begin{array}{c}\text { Retribusi } \\
\text { Tempat } \\
\text { Rekreasi dan } \\
\text { Olah Raga }\end{array}$ & & $\begin{array}{c}\text { PHR } \\
(\%)\end{array}$ & $\begin{array}{l}\text { Retribusi } \\
\quad(\%)\end{array}$ & $\begin{array}{c}\text { Total } \\
\%\end{array}$ \\
\hline 2002 & $21.163,51$ & $1.848,60$ & $54.386,43$ & 38,91 & 3,40 & 42,31 \\
\hline 2003 & $11.950,60$ & $1.426,17$ & $37.131,73$ & 32,18 & 3,84 & 36,03 \\
\hline 2004 & $20.384,76$ & $2.043,83$ & $48.541,65$ & 41,99 & 4,21 & 46,20 \\
\hline 2005 & $23.023,25$ & $2.107,73$ & $55.006,50$ & 41,86 & 3,83 & 45,69 \\
\hline 2006 & $25.816,92$ & $2.186,29$ & $67.838,57$ & 38,06 & 3,22 & 41,28 \\
\hline 2007 & $28.555,57$ & $2.900,19$ & $75.129,63$ & 38,01 & 3,86 & 41,87 \\
\hline 2008 & $43.586,18$ & $3.411,61$ & $96.922,24$ & 44,97 & 3,52 & 48,49 \\
\hline 2009 & $47.916,10$ & $4.176,37$ & $112.724,49$ & 42,51 & 3,70 & 46,21 \\
\hline 2010 & $62.918,10$ & $8.493,88$ & $153.617,90$ & 40,96 & 5,53 & 46,49 \\
\hline 2011 & $79.110,58$ & $11.121,42$ & $209.598,19$ & 37,74 & 5,31 & 43,05 \\
\hline 2012 & $86.104,71$ & $13.563,70$ & $261.222,18$ & 32,96 & 5,19 & 38,15 \\
\hline 2013 & $106.875,18$ & $12.518,30$ & $319.612,00$ & 33,44 & 3,92 & 37,36 \\
\hline 2014 & $145.070,52$ & $13.228,07$ & $424.782,24$ & 34,15 & 3,11 & 37,26 \\
\hline 2015 & $161.376,31$ & $13.619,90$ & $457.321,02$ & 35,29 & 2,98 & 38,27 \\
\hline 2016 & $206.849,40$ & $15.493,35$ & $529.864,62$ & 39,04 & 2,92 & 41,96 \\
\hline 2017 & $260.830,79$ & $18.782,66$ & $697.996,67$ & 37,37 & 2,96 & 40,06 \\
\hline \multicolumn{4}{|c|}{ Rata-rata } & 40,63 & 4,08 & 44,71 \\
\hline
\end{tabular}

Sumber: Data Penelitian, 2019

Sebagai sektor penggerak utama, sektor pariwisata menjadi faktor penentu utama pertumbuhan ekonomi Bali. Dengan demikian jika sektor tersebut mengalami gangguan, maka akan mendistorsi perekonomian secara keseluruhan. Pernyataan tersebut dapat dibuktikan dengan melihat pertumbuhan ekonomi pada triwulan IV-2004, ketika sektor PHR tumbuh 1,60 persen mendorong pertumbuhan ekonomi mencapai 2,72 persen. Sebaliknya ketika, pariwisata Bali mengalami gangguan dengan adanya serangan bom Kuta dan Jimbaran pada 1 Oktober 2005, yang selanjutnya diikuti oleh kontraksi pertumbuhan di sektor PHR menyebabkan kontraksi pertumbuhan ekonomi (Wijaya \& Yuliarmi, 2019).

Demikian pula di Kabupaten Gianyar, sektor pariwisata merupakan sektor unggulan dalam menunjang perolehan PAD. Hal tersebut ditunjukkan dengan rata-rata kontribusi pendapatan sektor pariwisata yang selama otonomi daerah sebesar 44,71 persen dalam PAD. 
Kemudian dari hasil penelitian terhadap data realisasi pendapatan sektor pariwisata dari PHR dan retribusi tempat rekreasi dan olah raga dari Badan Pengelolaan Keuangan dan Aset Daerah Kabupaten Gianyar menunjukkan pertumbumbuhan yang negatif pada tahun 2002 dan 2003 karena Bom Bali I. Namum pendapatan sektor pariwisata dapat tumbuh lagi seiring stabilnya keamanan Bali setelah tahun 2005. Jika dirata-ratakan pertumbuhan pertahunnya PHR mencapai 21,10 persen dan retribusi tempat rekreasi dan olah raga mencapai 19,48 persen. Untuk lebih lengkapnya dapat dilihat pada Tabel 5.

Tabel 5. Pertumbuhan Realisasi PHR dan Retribusi Tempat Rekreasi dan Olah Raga di Kabupaten Gianyar Tahun Anggaran 2002 - 2017

\begin{tabular}{ccccc}
\hline & \multicolumn{2}{c}{$\begin{array}{c}\text { Pendapatan Sektor Pariwisata } \\
\text { (dalam Rp. Juta) }\end{array}$} \\
\cline { 2 - 5 } Tahun & $\begin{array}{c}\text { Retribusi Tempat } \\
\text { Rekreasi dan } \\
\text { Raga }\end{array}$ & $\begin{array}{c}\text { Olah } \\
\text { PHR }\end{array}$ & $\begin{array}{c}\text { PHR } \\
(\%)\end{array}$ & Retribusi (\%) \\
\hline 2002 & $21.163,51$ & $1.848,60$ & - & - \\
2003 & $11.950,60$ & $1.426,17$ & $(43,53)$ & $(22,85)$ \\
2004 & $20.384,76$ & $2.043,83$ & 70,58 & 43,31 \\
2005 & $23.023,25$ & $2.107,73$ & 12,94 & 3,13 \\
2006 & $25.816,92$ & $2.186,29$ & 12,13 & 3,73 \\
2007 & $28.555,57$ & $2.900,19$ & 10,61 & 32,65 \\
2008 & $43.586,18$ & $3.411,61$ & 52,64 & 17,63 \\
2009 & $47.916,10$ & $4.176,37$ & 9,93 & 22,42 \\
2010 & $62.918,10$ & $8.493,88$ & 31,31 & 103,38 \\
2011 & $79.110,58$ & $11.121,42$ & 25,74 & 30,93 \\
2012 & $86.104,71$ & $13.563,70$ & 8,84 & 21,96 \\
2013 & $106.875,18$ & $12.518,30$ & 24,12 & $(7,71)$ \\
2014 & $145.070,52$ & $13.228,07$ & 35,74 & 5,67 \\
2015 & $161.376,31$ & $13.619,90$ & 11,24 & 2,96 \\
2016 & $206.849,40$ & $15.493,35$ & 28,18 & 13,76 \\
2017 & $260.830,79$ & $18.782,66$ & 26,10 & 21,23 \\
Rata-rata & & & 21,10 & 19,48 \\
\hline
\end{tabular}

Sumber: Data Penelitian, 2019

Beberapa usaha telah dilakukan Pemerintah Kabupaten Gianyar untuk mewujudkan target penerimaan retribusi daerah. Secara garis besar usaha ini ditempuh dengan cara melakukan intensifikasi pungutan Selain itu Pemerintah Kabupaten Gianyar juga dapat melakukan ekstensifikasi pungutan, yang meliputi penggalian sumber PAD yang baru sesuai dengan perundangundangan yang berlaku sepanjang potensi serta ada juga layanan yang diberikan pemerintah dan tidak bertentangan dengan kepentingan masyarakat.

Terjadi peningkatan yang sangat besar pada pendapatan retribusi tempat rekreasi dan olah raga, dimana tahun 2009 pendapatannya Rp. 4.176.374.647,00 menjadi Rp. 8.493.876.002,00 pada tahun 2010. Hal tersebut karena Pemerintah Kabupaten Gianyar menerbitkan Perda No. 8 Tahun 2010 sebagai salah satu bentuk intensifikasi pungutan yang menaikkan tarif retribusi dari Rp. 6000,00 menjadi 15.000,00 untuk orang dewasa, dan Rp.3.000,00 menjadi Rp. 7.500,00 untuk anak-anak. Kenaikan yang sangat besar tersebut menyebabkan rata-rata pertumbuhan kontribusi retribusi tempat rekreasi dan olah raga memiliki pertumbuhan yang cukup besar yaitu 19,48 persen. 
Pada tahun anggaran 2002 dan tahun 2003, terlihat bahwa persentase realisasi penerimaan retribusi obyek wisata mengalami penurunan pertumbuhan bahkan mencapai minus 18,36 persen pada tahun 2002 dan minus 22,85 persen pada tahun anggaran 2003. Pada tahun 2004 mengalami pertumbuhan cukup drastis yaitu 43,31 persen dan akhirnya kembali mengalami penurunan pertumbuhan, yaitu tumbuh sebesar 3,13 persen di tahun anggaran 2005. Selanjutnya di tahun 2006 meningkat menjadi 3,73 persen. Hal ini desebabkan oleh adanya tregedi Bom Bali II tahun 2005. Kemudian tampaknya mulai tahun 2007 pertumbuhannya naik menjadi 32,65 persen dan di tahun 2008 turun lagi menjadi 17, 63 persen, mencapai puncak pertumbuhan di tahun 2010 sebesar 103,38 persen (Tabel 5). Dan di tahun 2013 kembali terjadi penurunan sebesar 7,71 persen setelah itu mulai tahun 2014 kembali merangkak naik sehingga di tahun 2017 pertumbuhannya meningkat menjadi 21,23 persen.

Dengan lebih mengeintensifkan pemungutan retribusi obyek wisata diharapkan dapat meningkatkan perolehan retribusi obyek wisata yang signifikan bagi pendapatan daerah yang pada akhirnya akan lebih menunjukkan kemandirian keuangan daerah dan menunjukkan kemampuan pemerintah daerah di dalam membiayai sendiri kegiatan pemerintahannya.

Untuk mengetahui pengaruh pendapatan sektor pariwisata yang terdiri dari PHR dan retribusi tempat rekreasi dan olah raga di Kabupaten Gianyar periode 2002-2017, digunakan analisis regreasi linear berganda dengan menggunakan software SPSS versi 11. for Windows, maka diperoleh persamaan regreasi linear berganda sebagai berikut.

Tabel 6. Hasil Analisis Regresi Linier Berganda

\begin{tabular}{|c|c|c|c|c|c|c|}
\hline \multirow{2}{*}{\multicolumn{2}{|c|}{ Model }} & \multicolumn{2}{|c|}{$\begin{array}{l}\text { Unstandardized } \\
\text { Coefficients }\end{array}$} & \multirow{2}{*}{$\begin{array}{c}\begin{array}{c}\text { Standardized } \\
\text { Coefficients }\end{array} \\
\text { Beta }\end{array}$} & \multirow[t]{2}{*}{$\mathrm{t}$} & \multirow[t]{2}{*}{ Sig. } \\
\hline & & B & Std. Error & & & \\
\hline \multirow{4}{*}{1} & (Constant) & . 173 & 3.422 & & .051 & .000 \\
\hline & PHR & .026 & . 120 & .037 & 0.215 & .000 \\
\hline & Retribusi Tempat & & & & & \\
\hline & $\begin{array}{l}\text { Rekreasi dan Olah } \\
\text { Raga }\end{array}$ & 1.174 & .216 & .929 & 5.429 & .000 \\
\hline
\end{tabular}

Sumber: Data Penelitian, 2019

Berdasarkan hasil analisi regresi linier berganda maka dapat dijelaskan persamaan sebagai berikut.

$$
\mathrm{Y}=0,215 \mathrm{X}_{1}+5,429 \mathrm{X}_{2}
$$

Uji R2 (Koefisien Determinasi), digunakan untuk mengetahui ketepatan model yang digunakan dan dinyatakan dalam berapa persen variabel dependent dapat dijelaskan variabel-variabel independent yang dimasukan ke dalam model. Model dianggap baik apabila koefisien determinasi $\left(R^{2}\right)$ sama dengan atau mendekati 1. Maka hasil koefisien determinasi terdapat pada Tabel 7.

Dari hasil analisis regresi diperoleh nilai $\mathrm{R}^{2}$ sebesar 0,815 berarti bahwa 81,5\% persen variasi dari variabel dependent (Pendapatan Asli Daerah) dapat dipengaruhi oleh variasi variabel independent (PHR dan retribusi tempat rekreasi dan olah raga) sedangkan selebihnya sebesar 18,5\% dijelaskan oleh variabel lain di luar model yang terangkum dalam kesalahan random. 
Tabel 7. Hasil Uji Koefisien Dterminasi

\begin{tabular}{lrrrrr}
\hline Model & $\mathrm{R}$ & $\mathrm{R}$ Square & $\begin{array}{l}\text { Adjusted } \mathrm{R} \\
\text { Square }\end{array}$ & $\begin{array}{c}\text { Std. Error of the } \\
\text { Estimate }\end{array}$ & Durbin-Watson \\
\hline 1 & $.903^{\mathrm{a}}$ & .815 & .786 & .53959 & 2.168 \\
\hline
\end{tabular}

Sumber: Data Penelitian, 2019

Uji ini dilakukan untuk menguji hipotesis pengaruh secara simultan dan signifikan PHR dan retribusi tempat rekreasi dan olah raga Pendapatan Asli Daerah (PAD) Kabupaten Gianyar Tahun Anggaran 2002-2017. Untuk membuktikannya dilakukan dengan menggunakan uji $\mathrm{F}$ pada Tabel 8.

Tabel 8. Hasil Uji F

\begin{tabular}{rrrrrrr}
\hline Model & & Sum of Squares & df & Mean Square & F & Sig. \\
\hline \multirow{2}{*}{1} & Regression & 16.651 & 2 & 8.325 & 28.594 & $.000^{\mathrm{b}}$ \\
& Residual & 3.785 & 13 & .291 & & \\
& Total & 20.436 & 15 & & & \\
\hline
\end{tabular}

Sumber: Data Penelitian, 2019

Nilai F hitung yang diolah dengan SPSS adalah 28,594. Oleh karena F hitung $(28,594)>$ dari $\mathrm{F}$ tabel $(5,117)$, maka Ho ditolak. Ini berarti bahwa PHR dan retribusi tempat rekreasi dan olah raga secara simultan berpengaruh signifikan terhadap PAD Kabupaten Gianyar tahun 2002-2017.

Oleh karena $\mathrm{t}$ hitung $(12,441)>\mathrm{t}$ tabel $(1,860)$, Ho ditolak. Ini berarti bahwa pendapatan sektor pariwisata yang bersumber dari PHR berpengaruh positif dan signifikan secara parsial terhadap Pendapatan Asli Daerah (PAD) Kabupaten Gianyar. Tanda positif koefisien regresi 0,026 menunjukan bahwa pengaruh PHR terhadap PAD adalah positif (searah) artinya setiap penambahan 1 rupiah PHR akan berpengaruh terhadap peningkatan PAD Kabupaten Gianyar sebesar 0,026 rupiah per tahun dengan asumsi variabel lain bernilai konstan (ceteris paribus). Berdasarkan nilai koefisien regresi sebesar 0,026 maka dapat dikatakan bahwa adanya hubungan positif antara PHR terhadap PAD, semakin tinggi PHR maka semakin meningkat pula PHR.

Oleh karena t hitung $>\mathrm{t}$ tabel $(3,208>1,860)$ maka Ho ditolak. Ini berarti bahwa pendapatan sektor pariwisata yang bersumber dari retribusi tempat rekreasi dan olah raga berpengaruh secara parsial terhadap Pendapatan Asli Daerah (PAD) Kabupaten Gianyar. Tanda positif koefisien regresi 5,429 menunjukan bahwa pengaruh retribusi tempat rekreasi dan olah raga terhadap PAD adalah positif (searah) artinya setiap penambahan 1 rupiah retribusi tempat rekreasi dan olah raga akan berpengaruh terhadap peningkatan PAD Kabupaten Gianyar sebesar 5,429 rupiah per tahun dengan asumsi variabel lain bernilai konstan (ceteris paribus). Berdasarkan nilai koefisien regresi sebesar 5,429 maka dapat dikatakan bahwa adanya hubungan positif antara retribusi tempat rekreasi dan olah raga terhadap PAD, semakin tinggi retribusi tempat rekreasi dan olah raga maka semakin meningkat pula PAD.

Uji multikolinieritas bertujuan untuk mengetahui apakah dalam model regresi ditemukan adanya korelasi antar variabel bebas. Model regresi yang baik adalah model regresi yang tidak ada korelasi antar variable bebas. Untuk mengetahui bahwa model tidak terganggu oleh gejala multikolinieritas adalah dengan melihat nilai variance inflation factor (VIF); jika dalam model regresi nilai 
VIF lebih dari 10, menunjukkan adanya gejala multikolinieritas. Hasil uji kedua variabel bebas tersebut dapat dilihat pada Tabel 9.

Tabel 9. Perhitungan Tolerance Value (TOL) dan Variance Inflation Factor (VIF)

\begin{tabular}{|c|c|c|c|}
\hline \multirow[t]{2}{*}{ Mode } & & \multicolumn{2}{|c|}{ Collinearity Statistics } \\
\hline & & Tolerance & VIF \\
\hline \multirow[b]{2}{*}{1} & PHR & 487 & 2.054 \\
\hline & $\begin{array}{l}\text { Retribusi Tempat Rekreasi dan Olah } \\
\text { Raga }\end{array}$ & 487 & 2.054 \\
\hline
\end{tabular}

Sumber: Data Penelitian, 2019

Tabel 9, menunjukkan bahwa PHR (X1) dan retribusi tempat rekreasi dan olah raga (X2) dikaji dari koefisien VIF, berada dibawah 10 dan tolerance-nya diatas 0,205. Ini berarti tidak terjadi multikolinearitas antara PHR dan retribusi tempat rekreasi dan olah raga.

Uji heteroskedastisitas bertujuan untuk menguji apakah dalam model regresi terjadi ketidaksamaan varians dari satu pengamatan ke pengamatan yang lain. Model regresi yang baik adalah tidak ada heteroskedastisitas. Uji heteroskedastisitas yang digunakan dalam penelitian ini adalah uji Glajser. Hasil analisis heteroskedastisitas dapat dilihat pada Tabel 10.

Tabel 10. Hasil Uji Heteroskedastisitas

\begin{tabular}{|c|c|c|c|c|c|c|}
\hline \multirow[t]{2}{*}{$\overline{\mathrm{Mod}}$} & & \multicolumn{2}{|c|}{$\begin{array}{c}\text { Unstandardized } \\
\text { Coefficients }\end{array}$} & \multirow{2}{*}{$\begin{array}{c}\begin{array}{c}\text { Standardized } \\
\text { Coefficients }\end{array} \\
\text { Beta }\end{array}$} & \multirow[t]{2}{*}{$\mathrm{t}$} & \multirow[t]{2}{*}{ Sig. } \\
\hline & & $\mathrm{B}$ & Std. Error & & & \\
\hline \multirow{4}{*}{1} & (Constant) & 3.460 & 2.612 & & 1.325 & .208 \\
\hline & PHR & 131 & .091 & .506 & 1.439 & 174 \\
\hline & Retribusi Tempat & & & & & \\
\hline & $\begin{array}{l}\text { Rekreasi dan Olah } \\
\text { Raga }\end{array}$ & .312 & .165 & .665 & 1.890 & .081 \\
\hline
\end{tabular}

Sumber: Data Penelitian, 2019

Tabel 10, menunjukkan bahwa koefisien regresi dari PHR dan retribusi tempat rekreasi dan olah raga tidak berpengaruh nyata terhadap absolut nilai residual karena memiliki nilai signifikan $>0,05$. Oleh karena itu, uji heteroskedastisitas menunjukkan bahwa dalam model regresi yang diregres tidak terjasi heteroskedastisitas, sehingga model regresi tersebut dapat dipergunakan.

Autokolerasi dapat dilihat dari Regression Analysis. Dengan bantuan program SPSS dapat dikaji nilai Durbin Watson, yang dapat dipergunakan sebagai tolak ukur pengujian autokolerasi. Secara sistematis pengujian autokolerasi dilakukan sebagai berikut.

Tabel 11. Hasil Uji Autokorelasi

\begin{tabular}{|c|c|c|c|c|c|}
\hline Model & $\mathrm{R}$ & R Square & Adjusted R Square & $\begin{array}{l}\text { Std. Error of the } \\
\text { Estimate }\end{array}$ & Durbin-Watson \\
\hline$\overline{1}$ & $.903^{a}$ & .815 & .786 & .53959 & 2.168 \\
\hline
\end{tabular}

Sumber: Data Penelitian, 2019

Berdasarkan pengujian, maka didapat nilai Durbin-Watson sebesar 2,168. Kemudian jika dibandingkan pada $n=11$ (jumlah sampel adalah 11) dan dan jumlah variabel adalah 2, maka didapat nilai Durbin-watson dari hasil pengujian yang sebesar 2,168 berada pada rentang $\mathrm{dL}$ dan $\mathrm{dU}$, sehingga dapat disimpulkan 
tidak terjadi autokorelasi.

Setelah dilakukan ketiga uji asumsi klasik tersebut, model regresi PHR (X1) dan retribusi tempat rekreasi dan olah raga (X2) terhadap PAD Kabupaten Gianyar (Y) telah bebas dari masalah multikolinieritas, heteroskedastisitas, autokorelasi.

Kontribusi pendapatan sektor pariwisata selama delapan belas tahun otonomi daerah berlangsung menunjukkan kontribusi yang dominan dengan rata-rata 44,71 persen, dimana pendapatan sektor pariwisata dari pajak yaitu PHR menunjukkan kontribusi yang besar dengan rata-rata 40,63 persen dan retribusi tempat rekreasi dan olah raga menunjukkan peran yang masih kecil dengan rata-rata 4,08 persen. Dari hasil penelitian terlihat bahwa pendapatan sektor pariwisata khususnya dari PHR memiliki kontribusi yang cukup tinggi pada Pendapatan Asli Daerah (PAD) Kabupaten Gianyar hingga mencapai angka 40,63 persen dari total penerimaan PAD Kabupaten Gianyar. Namun kontribusi retribusi tempat rekreasi dan olah raga terhadap PAD masih cukup rendah yaitu hanya 4,08 persen, padahal jika dilihat dari potensi dan kondisi daerah sektor pariwisata Kabupaten Gianyar memiliki potensi yang cukup besar untuk meningkatkan pendapatan dari retribusi tempat rekreasi dan olahraga sehingga dapat memberikan sumbangan yang cukup berarti bagi penerimaan daerah namun kenyataannya kontribusinya masih rendah.

Berdasarkan hasil pengolahan diperoleh nilai $\mathrm{F}_{\text {-hitung }}$ sebesar 28,594 lebih besar dari $\mathrm{F}_{\text {tabel }}$ : 5,117 dengan tingkat signifikansi $0,000<a(0,05)$. Hal ini menandakan bahwa Ho ditolak dan HA diterima, artinyai PHR dan retribusi tempat rekreasi dan olah raga berpengaruh signifikan secara simultan terhadap Pendapatan Asli Daerah (PAD) Kabupaten Gianyar.

Dari hasil analisis regresi sederhana diperoleh adanya pengaruh positif dan nyata antara pendapatan sektor pariwisata yang diantaranya bersumber dari PHR dan retribusi tempat rekreasi dan olah raga terhadap PAD, hal ini dapat diketahui dari koefisien determinasinya (R2) sebesar 81,5\% ini berarti bahwa81,5\% persen variasi dari variabel dependent (Pendapatan Asli Daerah) dapat dipengaruhi oleh variasi variabel independent (PHR dan retribusi tempat rekreasi dan olah raga) sedangkan sisanya sebesar 18,5\% persen dijelaskan oleh variabel lain di luar model yang terangkum dalam kesalahan random. Hasil analisis regresi ini menjelaskan kondisi PHR dan retribusi tempat rekreasi dan olah raga terhadap PAD didasarkan atas data-data yang digunakan dalam analisis bukan dijelaskan oleh kondisi yang ada. Hal ini dapat dibuktikan secara statistik, baik secara individu masing-masing variabel ataupun secara bersamasama variabel independen tersebut terhadap variabel PAD.

Di Kabupaten Gianyar, sektor pariwisata merupakan sektor unggulan dalam menunjang perolehan PAD. Hal tersebut ditunjukkan dengan rata-rata kontribusi PHR kontribusi pendapatan sektor pariwisata yang selama otonomi daerah sebesar 47,71 persen dalam PAD. Mengingat besarnya pengaruh pendapatan sektor pariwisata terhadap PAD Kabupaten Gianyar sektor pariwisata perlu mendapatkan perhatian lebih. Alokasi dana untuk peningkatan perkembangan pariwisata seperti untuk promosi dan perawatan obyek wisata harus ditingkatkan dan digunakan dengan baik, sesuai ketentuan. 
Nilai $t_{\text {-hitung }}$ sebesar 12,441 lebih besar dari $t_{\text {tabel }}=1,860$ atau dengan tingkat signifikansi $0,000<a(0,05)$. thitung jatuh pada daerah penolakan Ho, sehingga ada pengaruh positif dan signifikan secara parsial dari variabel PHR terhadap PAD Kabupaten Gianyar. Tanda positif koefisien regresi 0,215 menunjukan bahwa pengaruh PHR terhadap PAD Kabupaten Gianyar adalah positif (searah), artinya setiap penambahan 1 rupiah PHR akan berpengaruh terhadap PAD Kabupaten Gianyar sebesar 0,215 juta rupiah per tahun dengan asumsi variabel lain bernilai konstan (ceteris paribus).

Hasil pengolahan data diperoleh Nilai $t_{\text {-hitung }}$ sebesar 3,208 lebih besar dari $\mathrm{t}_{\text {-tabel }}=1,860$ atau dengan tingkat signifikansi $0,000<\alpha(0,05) . t_{\text {-hitung }}$ jatuh pada daerah penolakan Ho, sehingga ada pengaruh signifikan secara parsial dari variabel retribusi tempat rekreasi dan olah raga terhadap PAD di Kabupaten Gianyar. Tanda positif koefisien regresi 5,498 menunjukan bahwa pengaruh retribusi tempat rekreasi dan olah raga terhadap PAD Kabupaten Gianyar adalah positif (searah), artinya setiap penambahan 1 rupiah retribusi tempat rekreasi dan olah raga akan berpengaruh terhadap PAD Kabupaten Gianyar sebesar 5,864 juta rupiah per tahun dengan asumsi variabel lain bernilai konstan (ceteris paribus).

Hasil penelitian ini diharapkan dapat memberikan tambahan informasi mengenai kontribusi serta pengaruh pendapatan sektor pariwisata seperti PHR dan retribusi tempat rekreasi dan olahraga pada pendapatan asli daerah. Terdapat bukti empiris bagi peneliti dalam pengaruh pendapatan sektor pariwisata seperti PHR dan retribusi tempat rekreasi dan olahraga terhadap pendapatan asli daerah.

Hasil penelitian ini dapat memberikan masukan bagi Pemerintah Daerah khususnya pemerintah Kabupaten Gianyar mengenai pengaruh yang signifikan dari pendapatan sektor pariwisata seperti PHR dan retribusi tempat rekreasi dan olahraga pada pendapatan asli daerah. Sehingga pemerintah daerah dapat menciptakan strategi untuk terus meningkatkan penerimaan dari pendapatan sektor pariwisata seperti PHR dan Retribusi tempat rekreasi dan olahraga.

\section{SIMPULAN}

Pendapatan sektor pariwisata dari PHR dan retribusi tempat rekreasi dan olah raga di Kabupaten Gianyar mempunyai kontribusi yang sangat tinggi terhadap pendapat asli daerah hingga mencapai rata-rata 47,71 persen. Angka yang cukup tinggi bagi penerimaan daerah dari sektor pariwisata.

Pendapatan sektor pariwisata dari PHR dan retribusi tempat rekreasi dan olah raga secara simultan berpengaruh signifikan terhadap Pendapatan Asli Daerah (PAD) Kabupaten Gianyar Tahun anggaran 2002 - 2017. Nilai R² sebesar $81,5 \%$ berarti bahwa $81,5 \%$ persen variasi dari variabel dependent (PAD Kabupaten Gianyar) dapat dijelaskan oleh variasi variabel independent (PHR dan retribusi tempat rekreasi dan olah raga), sedangkan sisanya sebesar 1 persen dijelaskan oleh variabel lain di luar model yang terangkum dalam kesalahan random.

Pendapatan sektor pariwisata dari PHR secara parsial berpengaruh positif dan signifikan terhadap Pendapatan Asli Daerah (PAD) Kabupaten Gianyar Tahun Anggaran 2002 -2017. Pendapatan sektor pariwisata dari retribusi tempat 
rekreasi dan olah raga secara parsial berpengaruh signifikan terhadap Pendapatan Asli Daerah (PAD) Kabupaten Gianyar Tahun anggaran 2002-2017.

Berdasarkan nilai koefisien regresi sebesar 0,026 maka dapat dikatakan bahwa adanya hubungan positif antara PHR terhadap PAD, semakin tinggi PHR maka semakin meningkat pula PHR.

Berdasarkan nilai koefisien regresi sebesar 5,429 maka dapat dikatakan bahwa adanya hubungan positif antara retribusi tempat rekreasi dan olah raga terhadap PAD, semakin tinggi retribusi tempat rekreasi dan olah raga maka semakin meningkat pula PAD.

Dengan diketahui pengaruh pendapatan sektor pariwisata terhadap Pendapatan Asli Daerah (PAD) yang sangat besar maka disarankan kepada Pemerintah Kabupaten Gianyar agar meningkatkan program-program yang berkaitan dengan promosi pariwisata baik melalui media cetak maupun elektronik agar dapat meningkatkan jumlah kunjungan wisatawan ke Kabupaten Gianyar dan melakukan kerjasama dengan pihak swasta dalam membuat program paket wisata. Contohnya melakukan kerja sama dengan pihak travel dan sekolah-sekolah, sehingga mereka bersedia mengajak tamu dan siswanya berkunjung ke obyek wisata yang ada di Kabupaten Gianyar.

Meningkatkan upaya untuk menegakkan peraturan pajak dengan mengambil tindakan tegas seperti penyegelan atau pembekuan sementara kegiatan usaha terhadap wajib pajak yang lalai membayar pajak. Selain itu mengintensifkan pengiriman surat peringatan kepada wajib pajak yang belum membayar kewajibannya juga perlu dilakukan.

Pemerintah Daerah Kabupaten Gianyar sebaiknya menambah serta memperbaiki fasilitas sarana dan prasarana yang menunjang pariwisata, dan menambah alokasi dana untuk pengembangan pariwisata.

\section{REFERENSI}

Gde Mantra Suarjana, A. A., Indah Kusuma Dewi, N., \& Mei Wahyuni, L. (2019). Pengaruh Kunjungan Wisatawan, Pajak Hotel dan Restoran terhadap Pendapatan Asli Daerah Pemerintah Kabupaten Gianyar-Bali. Jurnal Bisnis Dan Kewirausahaan, 15(1), 39. https://doi.org/10.31940/jbk.v15i1.1314

Hasiani., F. (2015). Analysis Of The Human Resources and The Impact On Economic Growth In Pelalawan Regency. Jom FEKON, 2(2), 1-15.

Kamila, A. (2016). Pengaruh Sektor Pariwisata, Produk Domestik Regional Bruto (PDRB), Tingkat Investasi dan Jumlah Penduduk terhadap Peningkatan Pendapatan Asli Daerah (PAD) Tahun 2010-2014. Skripsi. Sarjana Jurusan Akuntansi Fakultas Ekonomi dan Bisnis Universitas Muhammadiyah Surakarta.

Mayasari, D., \& Rahardjo, S. (2018). Peranan Aspek Ekonomis Pariwisata Kota Bogor Terhadap Pendapatan Asli Daerah. National Conference of Creative Industry, 2(3), 31-48. https:// doi.org/10.30813/ncci.v0i0.1196

Nugraha. (2014). Pengaruh Jumlah Kunjungan Wisatawan Terhadap Pajak Hiburan, Pajak Hotel, Pajak Restoran dan Pendapatan Asli Daerah Kota Bandung Tahun 2005-2012. (March).

Oomariyah, W. N. (2017). Kontribusi Pendapatan Sektor Pariwisata terhadap Pendapatan Asli Daerah Kabupaten Pacitanm2014-2016. Skripsi. Sarjana 
Jurusan Ilmu Ekonomi Syari'ah Fakultas Ekonomi dan Bisnis Islam UniversitasIslam Negeri Sunan Kalijaga.

Pleanggra, F., \& G, E. Y. a. (2012). Analisis Pengaruh Jumlah Obyek Wisata,Jumlah Wisatawan Dan Pendapatan Perkapita Terhadap Pendapatan Retribusi Obyek Pariwisata 35 Kabupaten/Kota Di Jawa Tengah. Diponegoro Journal of Economics, 1(1), 1-8.

Pratama, A. W. P. (2014). Analisis Pengaruh Pajak Daerah, Jumlah Wisatawan, dan Produk Domestik Regional Bruto (PDRB) terhadap Pendapatan Asli Daerah Kabupaten/Kota di Daerah Istimewa Yogyakarta. Skripsi. Sarjana Jurusan Ilmu Ekonomi Universitas Muhammadiyah Yogyakarta.

Purwanti, N. D., \& Dewi, R. M. (2014). Pengaruh Jumlah Kunjungan Wisatawan Terhadap Pendapatan Asli Daerah Kabupaten Mojokerto Tahun 2006-2013. Jurnal Fakultas Ekonomi, Universitas Negeri Surabaya, 2(3), 1-12.

Putra, I. W. B. N., Sujana, E., \& Purnamawati, I. G. A. (2017). Analisis Efektivitas Penerimaan dan Efisiensi Pemungutan Pajak Reklame serta Kontribusinya terhadap Pendapatan Asli Daerah Kabupaten Gianyar Tahun 2014-2016. EJournal S1 Ak Universitas Pendidikan Ganesha, 8(2).

Rahmawati, M. A. (2018). Analisis Sub Sektor Pariwisata terhadap Pendapatan Asli Daerah di Bali (Skripsi. Sarjana Jurusan Ilmu Ekonomi Fakulras Ekonomi Universitas Islam Indonesia). https://doi.org/10.1590/s180998232013000400007

Rasdiana, S. (2017). Kontribusi Pajak Pariwisata dan Retribusi Pariwisata terhadap Pendapatan Asli Daerah Kabupaten Bulukumba Periode 2006-2015. Skripsi. Sarjana Jurusan Ilmu Ekonomi Fakultas Ekonomi dan Bisnis Universitas Islam Negeri Alauddin Makassar.

Ratnawati, Y. (2016). Analisis Kontribusi Sektor Pariwisata Terhadap Pendapatan Asli Daerah Kabupaten Kutai Timur. Pendapatan, 1(3). Retrieved from https://www.neliti.com/id/publications/59489/analisis-kontribusi-sektorpariwisata-terhadap-pendapatan-asli-daerah-kabupaten \%0A

Rosa, Y. Del, Sovita, I., \& Idwar. (2016). Analisis Dampak Sektor Pariwisata Terhadap Pendapatan Asli Daerah Kabupaten Pesisir Selatan Tahun 2002014. Jurnal Ekonomi \& Bisnis Dharma Andalas, 18(1), 160-184.

Santosa Budi Purbayu, R. P. R. (2005). Analisis Pendapatan Asli Daerah (PAD) Dan Faktor-Faktor. Jurnal Dinamika Pembangunan, 2(1), 9-18.

Sijtsma, F. J., Broersma, L., Daams, M. N., Hoekstra, H., \& Werner, G. (2015). Tourism Development in the Dutch Wadden Area: Spatial-Temporal Characteristics and Monitoring Needs. Environmental Management and Sustainable Development, 4(2), 217. https://doi.org/10.5296/emsd.v4i2.8561

Spillane, J. J. (1994). Pariwisata Indonesia Siasat Ekonomi dan Rekayasa Kebudayaan Kanisius. Yogyakarta.

Statistik, B. P. (2018). Gianyar Dalam Angka.

Suahasil, N. (1997). Struktur Penerimaan Daerah Tingkat Provinsi di Indonesia. Prisma, 2(3), 17-26.

Swantara, I. K. B. P., \& Darsana, I. B. (2017). Pengaruh Kunjungan Wisatawan, Pendapatan PHR, dan Retribusi Obyek Wisata Terhadap Pad Kabupaten Gianyar. E-Jurnal EP Unud, 6(12), 2551-2582.

Thesaurianto, K. (2007). Analisis Pengelolaan Keuangan Daerah terhadap Kemandirian 
Daerah. Tesis. Program Pascasarjana Universitas Diponegoro Semarang.

Warda, A. Z. (2016). Pengaruh Jumlah Kunjungan Wisatawan terhadap Pendapatan Asli Daerah Sektor Pariwisata Kabupaten Kutai Kartanegara. EJournal Administrasi Bisnis Universitas Mulawarman, 6(1), 150-163.

Wijaya, P. A. G., \& Yuliarmi, N. N. (2019). Analisis Faktor-faktor yang Mempengaruhi Pendapatan Asli Daerah Kabupaten Badung. E-Jurnal EP Unud, 8(2), 359-388.

Wulandari, N. K. S., \& Triandaru, S. (2016). Peran Sektor Pariwisata dalam Pendapatan Asli Daerah Kabupaten Tabanan Tahun 1990-2014. Jurnal Fakultas Ekonomi, Universitas Negeri Surabaya Ekonomi, Universitas Atma Jaya Yogyakarta, 3(1).

Zulmi, F. (2018). Peranan Sektor Pariwisata terhadap Pendapatan Asli Daerah (PAD) di Provinsi Lampung. Skripsi. Sarjana Jurusan Ilmu Ekonomi Fakultas Ekonomi Universitas Islam Indonesia. 